\title{
Modification and Comprehensive Review on Vegetable oil as Green Lubricants (Bio-lubricants)
}

\author{
Zain Khalid ${ }^{* 1}$, Manzoor Ali ${ }^{* 2}$ \\ ${ }^{1}$ Student, Department of Petroleum, University of Karachi \\ ${ }^{2}$ Student, Department of Petroleum, University of Karachi
}

\begin{abstract}
:
As the petroleum fraction's demand increasing day by day in case of lubricating the parts of machinery. This also increase the problem of disposal of waste lubricant that may contaminate the soil and water environment and the depletion of petroleum reserve also brought the interest of researchers toward developing the lubricants that should be environmental friendly and also obtained from the source that should be in bulk quantity and easily obtainable. In this regards, vegetable oil is selected to be used as lubricant because it has some competent properties like higher flash point, fire point, viscosity index and the Tribological properties are better than the mineral oil based lubricant. Like Tribological properties of soybean oil with the different proportion of ZDDP is investigated and compared with mineral oil, results show that less wear and tear is observed. Similarly, the physical properties of jatropha oil was compared with the engine oil and hydraulic oil. The results show that the jatropha oil has less coefficient of friction and wear scar diameter than the engine oil and can be used as engine oil with the improvement in its viscosity. along with soybean and jatropha oil, anti-wear properties of the karanja oil blended with benzoic acid and ZDDP separately investigated and results showed that karanja oil can also be used as lubricant instead of mineral based lubricant. But karanja oil has drawback of high pour point than the mineral oil which is modified by using the polymethacrylate as a pour point depressant and lower the pour point from $1{ }^{\circ} \mathrm{C}$ to $-11^{\circ} \mathrm{C}$ with the addition of $1 \%$ in karanja oil. Overall results about vegetable oil show that vegetable oil modified with different chemical can be used as a lubricant in the industry with relatively low priced than the available lubricants in the market. These vegetable oil might be extracted in the Asian countries in a bulk quantity.
\end{abstract}

\section{Introduction:}

A lubricant is a fluid that have some unique properties which helps to lowers the friction between the parts of the machinery that in-turn reduce the wear and tear between the parts of the machine. It is basically a mixture of mineral base oil about $90 \%$ and $10 \%$ additive required for the proper lubrication of the engine parts (1). The consumption of the lubricants based on mineral oil is about 40 million tones and it is increasing day by day while increment is expected about $1.6 \%$ annually for the next 3 years (2). This ratio shows that there has been growing demand of mineral oil's lubricants as well as increases the environmental issues due to these mineral oil because after use their disposal is a big issue due to the inability of disintegration in the environment. This issue arises the research in developing the lubricants that are environment friendly based on vegetable oil like sunflower oil, soybean oil, etc. Environmental friendly or green lubricants are renewable and frequently made up of vegetable oils e.g. rapeseed, canola, corn oil, artificial esters and severally hydro treated crude primarily based oils. Compared to mineral and artificial oils, 
vegetable oils have variety of distinct benefits as well as considerably higher lubricity and viscouness, lower volatility and better shear stability. With higher biodegradable and toxicity properties than typical crude primarily based products, vegetable oils have tremendous potential to be used within the industrial sector (3). Vegetable oil like: soybean, rapeseed (Canola), sunflower, peanut, olive oil and others vegetable oils mainly composed of triglyceride molecular structures and have a great advantage in their performances which include poor thermal, hydrolytic and oxidation stability but genetic improvements on their seeds have also helped to overcome some of the thermal and oxidation stability disadvantages, especially with soybean and canola oils (4). Similarly, Rathore and Madras studied a supercritical method of biodiesel production of methanol and ethanol from Jatropha oil. they fixed a 50:1 alcohol to oil molar ratio under $20 \mathrm{~Pa}$ at $300^{\circ} \mathrm{C}$ for 10 minutes. Around $70 \%$ of the Jatropha oil was converted into fatty acid methyl esters and after 40 minutes this amount increased to $85 \%$. They obtained a higher percentage of conversion by controlling and optimizing the reactor up to $95 \%$ at $400^{\circ} \mathrm{C} \mathrm{(5).} \mathrm{Another} \mathrm{reason} \mathrm{that} \mathrm{give} \mathrm{chance} \mathrm{to}$ increase the research on vegetable oil as a bio-lubricants is the increasing prices of the mineral oil and the depletion of the crude oil reserve in the world. Bio-lubricating oils are perceived as alternatives to mineral oil because they possess certain natural technical properties and they are bio-degradable. Compared with mineral oils. Vegetable oil-based bio-lubricants generally exhibit high lubricity, high viscosity index (VI), high flash point, and low evaporative losses (6).

\section{Literature Review:}

1. A Study of Wear Properties of Different Soybean Oils: In this research, wear properties of three type of soybean is extracted from different sources are investigated using a four ball wear tester using the anti-wear additive Zinc Dithiophosphate (ZDDP) and soybean includes, conventional soybean oil, expoxidized soybean oil and high oleic soybean oil. in order to investigate the anti-wear properties of soybean with ZDDP, $1 \%$ of ZDDP is added in each soybean oil. After that, test the sample under different condition includes 25,50 and $75^{\circ} \mathrm{C}$ temperature and the speed of 600.900 and $1200 \mathrm{rpm}$. The results of each test is shown in figure-1, figure- 2 and figure-3. Now the combined results of the conditions like temperature, speed and light load with ZDDP didn't show the clear and smooth trend on the wear and friction of the soybean oils. But addition of ZDDP shows the protection against the scratches on the rubbing surface of the balls (7).

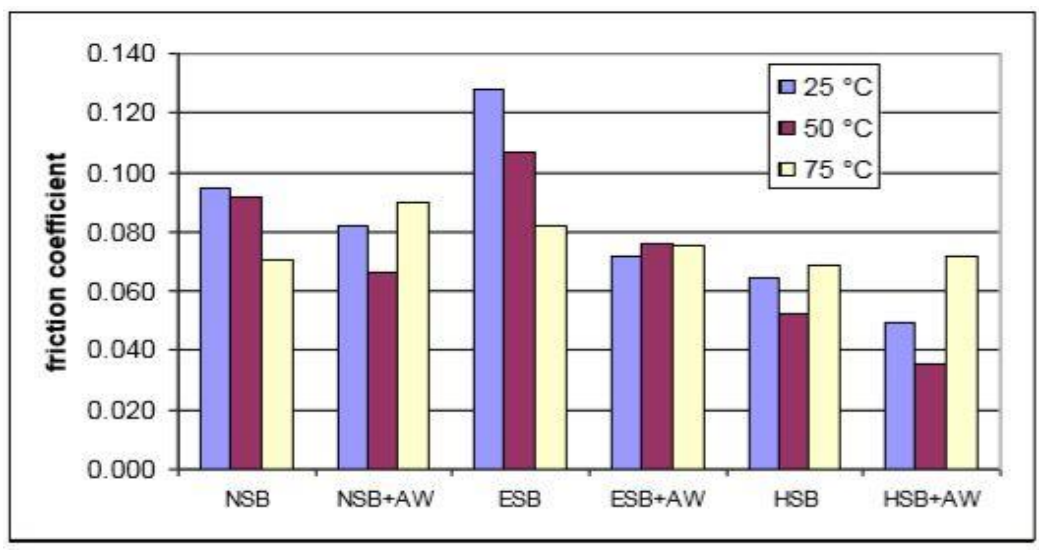

Figure-1 [Friction coefficients at $600 \mathrm{rpm}$ ] 


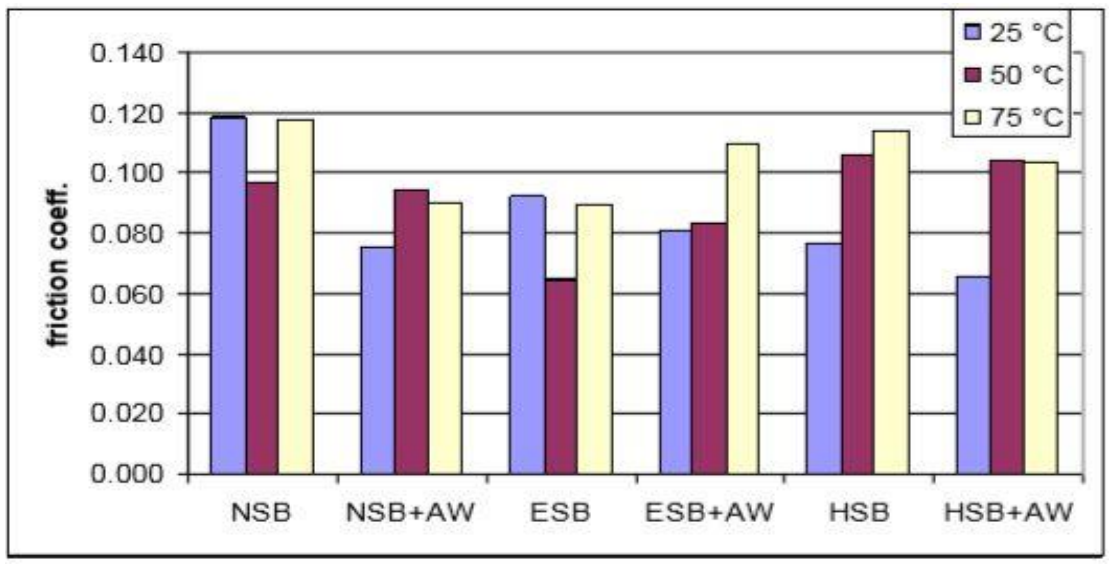

Figure-2 [Friction coefficients at $900 \mathrm{rpm}$ ]

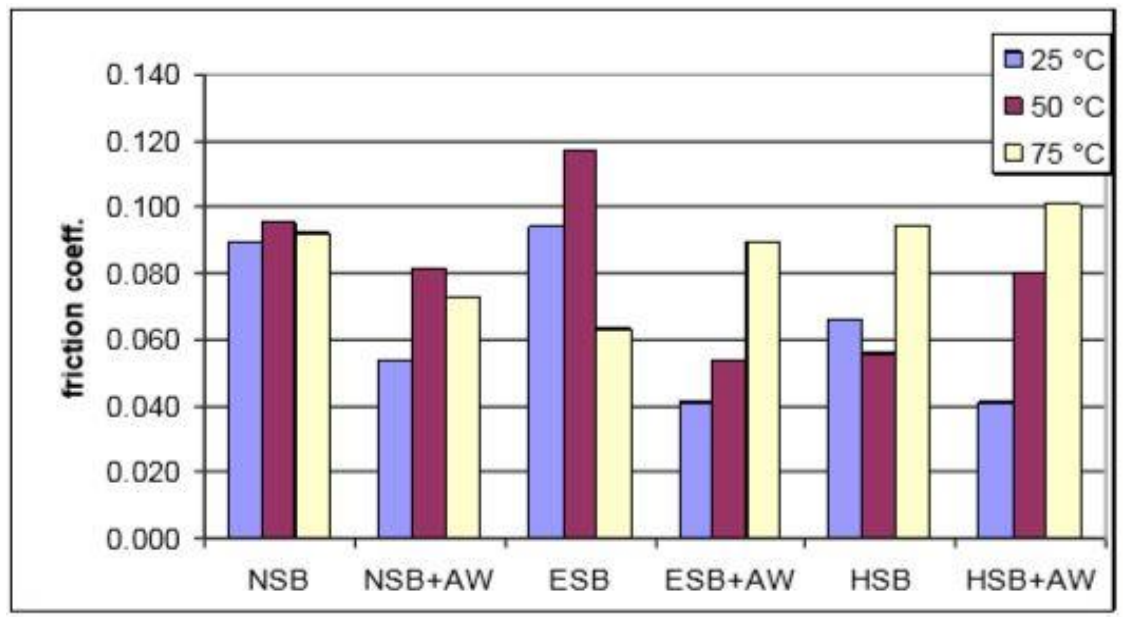

Figure-3 [Friction coefficients at $1200 \mathrm{rpm}$ ]

2. Comparative study of lube oils synthesized from chemically modified castor and soybean oils using additive: As we know that due to the non-biodegradability continuous use of petroleum lube oil resultsin environmental pollution. Comparatively, vegetable oils are biodegra dable, renewable and less toxic. Therefore, in this research paper soybean and castor oil are shown as potential source for synthesizing bio lube by separately mixing styrene as additive. For this purpose, 12 samples were prepared by mixing: 10, 20,30, 40 and 50\% styrene as additive with 100, 90, 80,70, 60 and 50\% soya and castor respectively. (table-1). ASTM IP, ubbelohde and $\mathrm{BS} / \mathrm{U}$ viscometer is used to measure kinematic viscosity (KV) and SYD-3536 Cleveland-opencup-tester was used to measure flash point. Standard methods have been used to measure pour point and acid number. Higher is the mass of oil the higher is its density (table-1) and hence, the higher pour point(PP) for soya bean, however castor cannot follow high mass high density and PP phenomenon (table-2). Standard test methods and properties of monograde SAE30, SAE40 and SAE50 lubricant where use as a reference for this study(table-3). Comparing the values of standard grade oil in table-4 to the tested values in table 2,3 and 6, although the values are a bit higher than standard grade oils, but can be used as a replacement for petroleum base oil. Soybean 
can replace base oil SAE15W-SAE20 monograde lubricant while castor can replace SAE50SAE60 (table-4), comparing it to the viscosities measure at 40 and 100 degrees Celsius (table$5)$. The only drawback is that the densities of sample 7-10 are slightly exceeded the specification $(0.99 \mathrm{~g} / \mathrm{ml})(\mathbf{8})$.

\begin{tabular}{|c|l|c|c|c|c|}
\hline $\begin{array}{l}\text { Sample } \\
\#\end{array}$ & Vegetable Oil Sample & $\begin{array}{l}\text { Volume of Oil } \\
\text { Sample (ml) }\end{array}$ & $\begin{array}{l}\text { Volume of } \\
\text { Additive (ml) }\end{array}$ & Mass of Oil (g) & $\begin{array}{l}\text { Oil Density } \\
\text { (g/ml) }\end{array}$ \\
\hline \hline $\mathbf{1}$ & Soybean Oil & 50 & 50 & 48.50 & 0.972 \\
\hline $\mathbf{2}$ & Soybean Oil & 60 & 40 & 48.50 & 0.972 \\
\hline $\mathbf{3}$ & Soybean Oil & 70 & 30 & 48.45 & 0.969 \\
\hline $\mathbf{4}$ & Soybean Oil & 80 & 20 & 48.25 & 0.965 \\
\hline $\mathbf{5}$ & Soybean Oil & 90 & 10 & 48.10 & 0.962 \\
\hline $\mathbf{6}$ & Soybean Oil & 100 & 0 & 45.80 & 0.916 \\
\hline $\mathbf{7}$ & Castor Oil & 50 & 50 & 51.25 & 1.025 \\
\hline $\mathbf{8}$ & Castor Oil & 60 & 40 & 50.95 & 1.019 \\
\hline $\mathbf{9}$ & Castor Oil & 70 & 30 & 50.45 & 1.009 \\
\hline $\mathbf{1 0}$ & Castor Oil & 80 & 20 & 50.20 & 1.004 \\
\hline $\mathbf{1 1}$ & Castor Oil & 90 & 10 & 48.20 & 0.964 \\
\hline $\mathbf{1 2}$ & Castor Oil & 100 & 0 & 47.95 & 0.959 \\
\hline
\end{tabular}

Table-1

\begin{tabular}{|c|c|c|c|}
\hline Lube Oil Sample \# & Pour Point $\left({ }^{\circ} \mathbf{C}\right)$ & Flash Point $\left({ }^{\circ} \mathbf{C}\right)$ & Acid Number $(\mathbf{m g} \mathbf{K O H} / \mathbf{g})$ \\
\hline $\mathbf{1}$ & -8 & 340 & 0.301 \\
\hline $\mathbf{2}$ & -8 & 335 & 0.514 \\
\hline $\mathbf{3}$ & -10 & 326 & 0.763 \\
\hline $\mathbf{4}$ & -11 & 318 & 0.978 \\
\hline $\mathbf{5}$ & -14 & 307 & 1.264 \\
\hline $\mathbf{6}$ & -16 & 300 & 2.346 \\
\hline $\mathbf{7}$ & 3 & 277 & 0.184 \\
\hline $\mathbf{8}$ & 2.2 & 276 & 0.191 \\
\hline $\mathbf{9}$ & 2 & 263 & 0.209 \\
\hline $\mathbf{1 0}$ & -2 & 261 & 0.217 \\
\hline $\mathbf{1 1}$ & -1 & 256 & 0.224 \\
\hline $\mathbf{1 2}$ & -2 & 250 & 1.101 \\
\hline
\end{tabular}

Table-2

\begin{tabular}{|c|c|c|c|}
\hline Properties & SAE 40 & SAE 30 & SAE 50 \\
\hline Density @ 15 (g/ml) & 0.9573 & 0.9279 & 0.903 \\
\hline Kinematic Viscosity @ $40^{\circ} \mathrm{C}\left(\mathrm{mm}^{2} / \mathrm{s}\right)$ & 154 & 112.4 & 273.7 \\
\hline Kinematic Viscosity @ $100^{\circ} \mathrm{C}\left(\mathrm{mm}^{2} / \mathrm{s}\right)$ & 14.5 & 12 & 19 \\
\hline Flash Point $\left({ }^{\circ} \mathrm{C}\right)$ & 240 & 240 & 240 \\
\hline Pour Point $\left({ }^{\circ} \mathrm{C}\right)$ & -27 & -30 & -24 \\
\hline
\end{tabular}




\begin{tabular}{|c|c|c|}
\hline SAE Viscosity Grades & $\begin{array}{c}\text { Kinematic Viscosity @ } \mathbf{1 0 0}^{\circ} \mathbf{C} \\
\left(\mathbf{m m}^{\mathbf{2}} \mathbf{/ s}\right) \text { Minimum }\end{array}$ & $\begin{array}{c}\text { Kinematic Viscosity @ } \mathbf{1 0 0}{ }^{\circ} \mathbf{C} \\
\left(\mathbf{m m}^{\mathbf{2}} \mathbf{/ s}\right) \text { Maximum }\end{array}$ \\
\hline \hline $\mathbf{1 5 W}$ & 5.6 & -- \\
\hline $\mathbf{2 0 W}$ & 5.6 & -- \\
\hline $\mathbf{2 5 W}$ & 9.3 & -- \\
\hline $\mathbf{2 0}$ & 5.6 & $<9.3$ \\
\hline $\mathbf{3 0}$ & 9.3 & $<12.5$ \\
\hline $\mathbf{4 0}$ & 12.5 & $<16.3$ \\
\hline $\mathbf{5 0}$ & 16.3 & $<21.9$ \\
\hline $\mathbf{6 0}$ & 21.9 & $<26.1$ \\
\hline
\end{tabular}

Table-4 (9)

\begin{tabular}{|c|c|c|}
\hline Lube oil Sample \# & Kinematic Viscosity @ $40^{\circ} \mathrm{C}\left(\mathrm{mm}^{2} / \mathrm{s}\right)$ & Kinematic Viscosity @ $100^{\circ} \mathrm{C}\left(\mathrm{mm}^{2} / \mathrm{s}\right)$ \\
\hline 1 & 125.13 & 12.8 \\
\hline 2 & 105.4 & 1.34 \\
\hline 3 & 98.2 & 10.22 \\
\hline 4 & 70.5 & 8.8 \\
\hline 5 & 50.16 & 8.3 \\
\hline 6 & 33.14 & 7.92 \\
\hline 7 & 450.92 & 47.7 \\
\hline 8 & 421.72 & 40.7 \\
\hline 9 & 371.01 & 35.2 \\
\hline 10 & 298.38 & 30.1 \\
\hline 11 & 274.52 & 24.4 \\
\hline 12 & 240.56 & 19.5 \\
\hline
\end{tabular}

Table-5

3. Investigation of physical properties for jatropha oil in different temperature as lubricant oil: In this research paper the properties of jatropha oil have been investigated to find clean, new and renewable source of lubricant oil. The anti-wear, anti-friction, flash temperature parameter (FTP) and viscosity index have been examined under 55, 75, 95, 105 and $125 \mathrm{C}^{0}$. Standard test method ASTM-D4172, four ball tribotester, CCD camera, digital microscope and viscometer have been used to perform experiment. The results under various temperature were compared with standard engine oil and hydraulic oil to evaluate the lubricating properties of jatropha oil. As viscosity has important role in lubricant ability, as it effects film thickness and therewith the wear rate of sliding surface. Increased viscosity normally indicates deteriorated oil by contamination or oxidation. The experiment shows that jatropha oil has better viscosity comparatively, at lower temperature it has excellent viscosity and with increasing temperature it shows better results till than engine oil and hydraulic oil as shown in graph-1. Flash temperature parameter (FTP) results are also comparatively good under various temperature. As $\mathrm{FTP}=\left(\mathrm{w} / \mathrm{d}^{1.4}\right)$ where $\mathrm{W}$ is load and $\mathrm{d}$ is wear scar diameter(WSD), hence, higher the FTP lower the WSD. The values of the flash temperature parameter of all the tested oils have been shown in graph- 2 . Jatropha oil has highest of values than hydraulic and engine oil therefore, having lower WSD value. Graph-3 compares the influence of temperature on co-efficient of friction. It can be seen clearly jatropha oil had a little ups and downs between 50 and $95 \mathrm{C}^{\mathrm{O}}$ but jatropha oil had better 
results. The chain fatty acid molecules in jatropha oil structure are the main reason to reduce wear and friction between contact parts, lower wear results can be seen in Figure-4. Therefore, jatropha oil can be used as lubricant with better anti-wear and anti-friction properties under various temperatures (10).
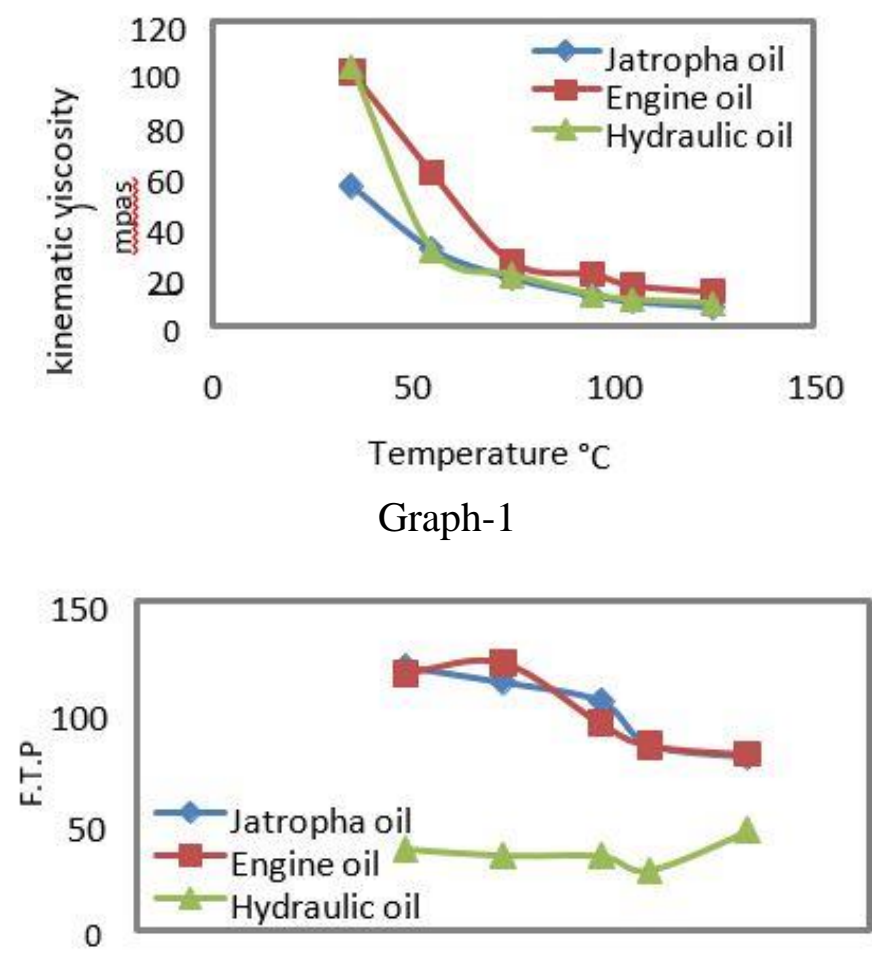

Graph-2

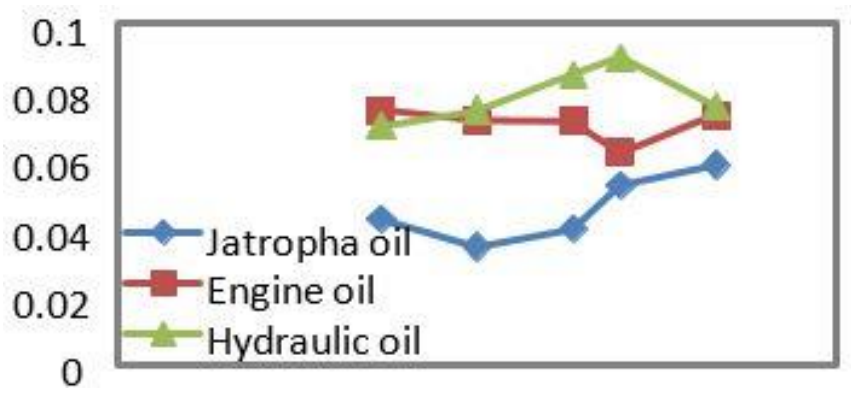

Graph-3
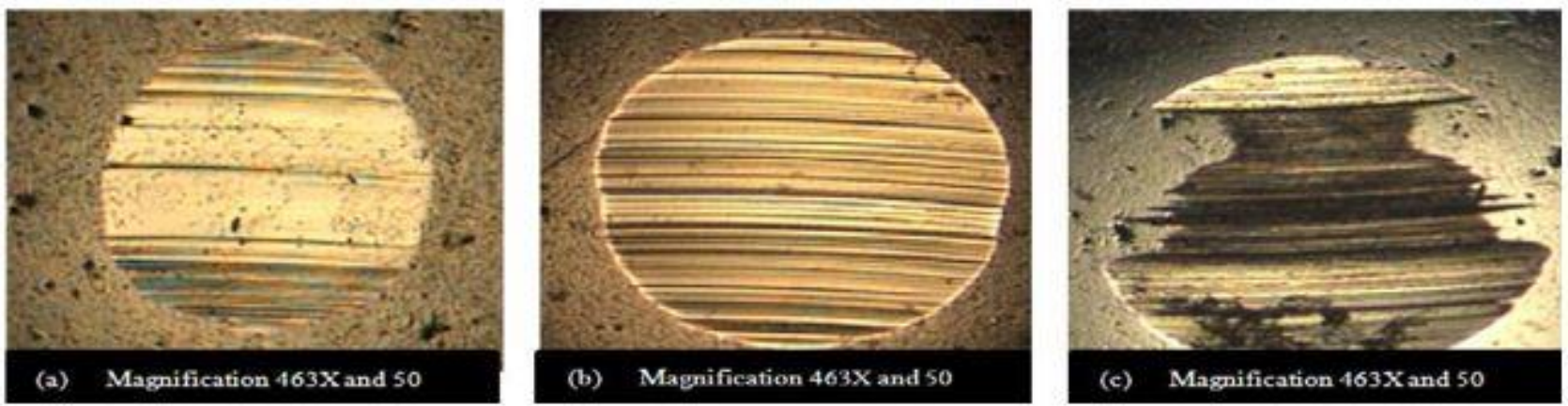

Figure-4 (a)Jatropha oil, (b) engine mineral oil, (c) hydraulic mineral oil 


\section{4. lubricity of bio-based lubricant derived from different chemically modified fatty acid} methyl ester: In this research paper trimethylolpropane(TMP) and pentaerythriol(PE) ester have been shown as possible source of bio-lubricant. TMP and PE are produce from palm oil methyl ester. Several tests have been done to compare the lubricating properties of TMP and PE to that of fully formulated lubricant (FFL) and paraffin oil. Four ball machine (FBM) was used to find out the effect of esters under boundary and extreme conditions. Coefficient of friction (COF) and wear scar diameter (WSD) were find out using FBM. Extreme pressure condition test standard was ASTM-2783. Over testing with different loads PE is having lowest COF and best extreme pressure characteristic as compare to all other simples as shows in figure 5-8. TMP and PE esters improved the load carrying capacity and function of lubricant up to the high load. PE ester had lowest WSD at low load compare to all other samples as shows in figure-9. In addition, the TMP and PE are having comparative minimum film thickness and film thickness ratio as shows in table- 6 . Furthermore, increase in number of ester group leads to greater binding of molecules therefore, results into great resistance to shear forces. Thermal, oxidative and hydrolytic stabilities need to be examined in order to make bio-lubricant more productive (11).

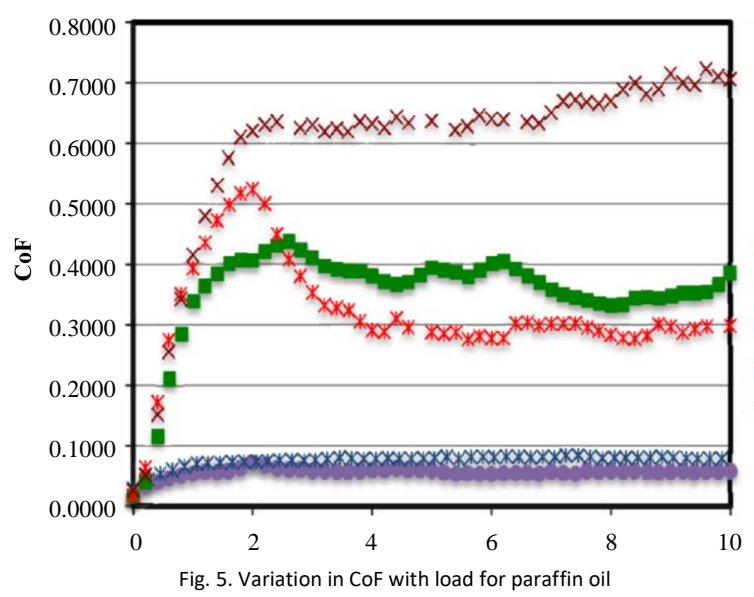

$196 \mathrm{~N}$

$* 392 \mathrm{~N}$

$\square 58 \mathrm{~N}$

*.785 N

$\times 981 \mathrm{~N}$

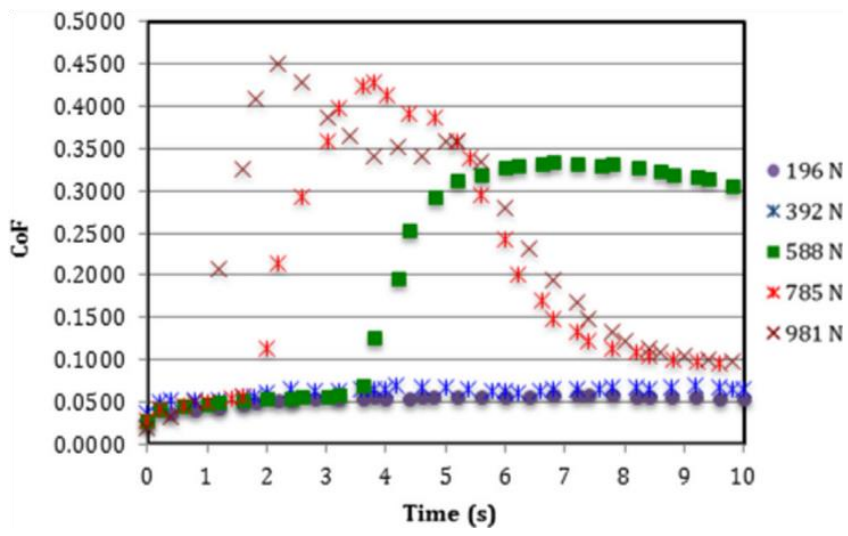

Fig. 7. Variation in CoF with load for TMP ester

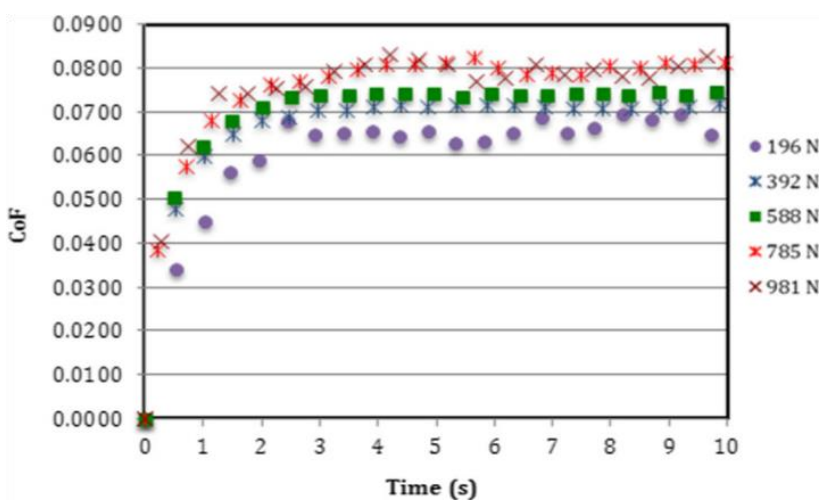

Fig. 6. Variation in CoF with load for FFL

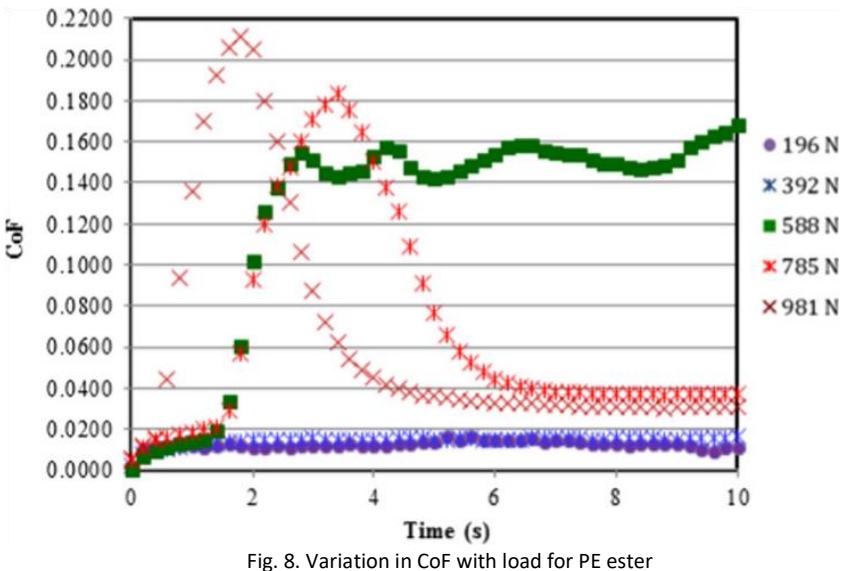




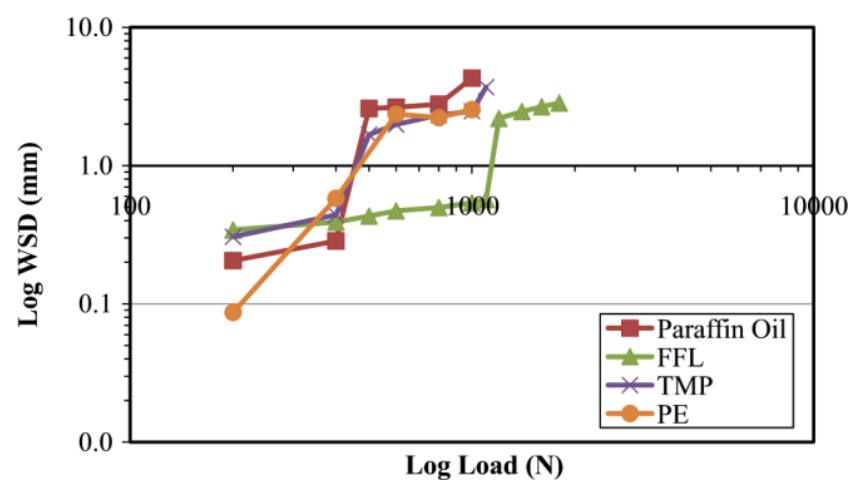

\begin{tabular}{llcc}
\hline Sample & Min film thickness $(\mu \mathrm{m})$ & Film thickness ratio & Lubrication regime \\
\hline Paraffin oil & 0.0273 & 1.0 & Boundary \\
FFL & 0.0359 & 1.3 & Mixed lubrication \\
TMP & 0.0469 & 1.7 & Mixed lubrication \\
PE & 0.0539 & 1.9 & Mixed lubrication \\
\hline
\end{tabular}

Table-6 Calculated film thickness at $392 \mathrm{~N}$ load.

Fig. 9. Relationship between load and wear scar diameter (WSD)

5. The prospect of bio-lubricant as alternative in automotive application: In this comprehensive review paper, bio-lubricant have been discussing as an alternative for mineral based lubricant. As we know that at present the increasing price of crude oil, the depletion of oil reserves and the global concern in protecting environment from pollution have developed interest in new environment friendly lubricant. Vegetable oil has proved to be a best suitable alternative because of its good lubricating characteristics and widespread sources. More than 350 oil bearing crops are known having good oil content some of the top crops have been mentioned in table-7. The characteristics of good lubricant are: high viscosity index (VI), high boiling point, thermal stability, low freezing point, corrosive protection and resistance to oxidation, bio-lubricant mostly have all these properties. Furthermore, bio-lubricants have suitable and useful physicochemical properties, they have more technical advantages than petroleum based lubricants. They have high lubricity, high VI, high flash point and low evaporative properties. Overall, vegetable based bio-lubricant are having several dominating properties as compare to that of mineral based lubricants as shown in table-8. High VI ( 230 commonly compare to that of 90-100 of mineral based oils) which indicates bio-lubricant can have good performance even in high temperatures. Moreover, vegetable based lubricants have lower pour point which means at lower temperatures bio-lubricants have good performance thus providing excellent lubrication for cold seasons. Their high flash point (326C commonly while $200 \mathrm{C}$ for mineral based oils) properties make them less hazardous and reducing risk of fire when leak. Therefore, some research has been done and prove the vegetable oil as alternative in automotive application. On its negative side vegetable oil in their natural form lacks oxidative stability for lubrication application, which is an area of concern (12). 


\begin{tabular}{ccccc}
\hline Sl. no. & Non-edible species & $\begin{array}{c}\text { Oil content } \\
\text { (\% of volume) }\end{array}$ & Edible species & $\begin{array}{c}\text { Oil content } \\
\text { (\% of volume) }\end{array}$ \\
\hline 1 & Jatropha & $40-60$ & Rapeseed & $38-46$ \\
2 & Neem & $30-50$ & Palm & $30-60 \mathrm{~b}$ \\
3 & Karanja & $30-50$ & Peanut & $45-55$ \\
4 & Castor & $45-60$ & Olive & $45-70$ \\
5 & Mahua & $35-50$ & Corn & 48 \\
6 & Linseed & $35-45$ & Coconut & $63-65$ \\
7 & Moringa & $20-36$ & - & - \\
\hline
\end{tabular}

Table-7 Oil content statistics of some non-edible and edible oil seeds

\begin{tabular}{lll}
\hline Properties & Vegetable oils & Mineral oils \\
\hline Density @201C $\left(\mathrm{kg} / \mathrm{m}^{3}\right)$ & 940 & 880 \\
Viscosity index & $100 \ldots 200$ & 100 \\
Shear stability & Good & Good \\
Pour point, 1C & $20 \ldots . .10$ & 15 \\
Clod flow behavior & Poor & Good \\
Miscibility with mineral oils & Good & - \\
Solubility in water & Not miscible & Not miscible \\
Oxidation stability & Moderate & Good \\
Hydrolytic stability & Poor & Good \\
Sludge forming tendency & Poor & Good \\
Seal swelling tendency & Slight & Slight \\
\hline
\end{tabular}

Table-8 Comparative analysis of properties of vegetable oils

6. Anti-wear properties of Benzoic Acid in Karanja Oil: In this research, anti-wear properties of Benzoic acid in Karanja Oil is investigated. For the testing of friction and viscosity tests, Four ball tester Tr-30L-PNU0IAS DUCOM material characterization system and BROOKFIELD DVT extra viscometer, USA are used respectively. In a Four Ball tester, tests for Coefficient of friction (COF) and Wear Scar Diameter Values (WSD) are conducted under the test condition of $392 \mathrm{~N}$ load, $75^{\circ} \mathrm{C}, 120 \mathrm{RPM}$ and 3600 seconds and chromium alloy steel balls are used as per specification given by the ASTM D-2783 (13). while the viscosity is measured at $40^{\circ} \mathrm{C}$ and $100^{\circ} \mathrm{C}$ according to ASTM D-445 (14). Now, Benzoic acid is blended in Karanja Oil in the weight concentration of $1 \%, 1.5 \%, 2 \%, 2.5 \%$ and $3 \%$. After blended, the sample's viscosity at $40^{\circ} \mathrm{C}$ and $100^{\circ} \mathrm{C}$ are conducted after that wear properties are find out by conducting the four ball test. The results of the COF and WSD is obtained with the help of Transmission Electron Microscope (TEM) and the images of for each ball shows the wear scar. It is found that addition of benzoic acid shows great results for the wear properties in Karanja oil and can be used as additive for antiwear in Karanja Oil because friction coefficient and wear scar diameter is decreased by adding the 
benzoic acid in Karanja oil as shown in table-9 while viscosity is also increase to some extend as shown in table-10 (15).

\begin{tabular}{|c|c|c|c|}
\hline $\begin{array}{c}\text { Sl } \\
\text { No }\end{array}$ & $\begin{array}{c}\text { Weight \% } \\
\text { Benzoic acid }\end{array}$ & COF & WSD \\
\hline 1 & 0 & 0.0551 & 438.48 \\
\hline 2 & 1 & 0.675 & 433.43 \\
\hline 3 & 1.5 & 0.0585 & 428.39 \\
\hline 4 & 2 & 0.0428 & 420.45 \\
\hline 5 & 2.5 & 0.0653 & 513.44 \\
\hline 6 & 3 & 0.0656 & 525.03 \\
\hline
\end{tabular}

Table-9

\begin{tabular}{|c|c|c|c|}
\hline $\begin{array}{c}\text { \% } \\
\text { Concentra } \\
\text { tion }\end{array}$ & $\begin{array}{c}\text { Dynamic } \\
\text { Viscosity } \\
\text { at } \mathbf{4 0} \text { c }\end{array}$ & $\begin{array}{c}\text { Dynamic } \\
\text { Viscosity } \\
\text { at } \mathbf{1 0 0} \text { c }\end{array}$ & $\begin{array}{c}\text { Viscos } \\
\text { ity } \\
\text { index }\end{array}$ \\
\hline 0 & 41.77 & 8.01 & 147 \\
\hline 1 & 43.56 & 10.75 & 162 \\
\hline 1.5 & 53.33 & 10.53 & 150 \\
\hline 2 & 51.64 & 10.54 & 152 \\
\hline 2.5 & 49.13 & 10.5 & 134 \\
\hline 3 & 38.19 & 8.31 & 131 \\
\hline
\end{tabular}

Table-10

7. Experimental Analysis of Tribological Properties of hBN Nanoparticles Additive in Castor \& Mahua Oil Blend: In this research article, castor oil blended with Mahua oil in 65\% and $35 \%$ respectively in order to test the wear and friction properties without any additive and with different proportion of $\mathrm{hBN}$ (hexagonal Boron nitrate). $\mathrm{hBN}$ was added in the blend of castor and Mahua oil with percentage as shown in table-11. After that every sample is tested for the wear and friction properties with the help of Four Ball Tribotester according to the ASTM D4172. The required condition for the test was set as temperature at $75^{\circ} \mathrm{C}$, speed $1200 \mathrm{rpm}$, time: 60 minutes and Load $392 \mathrm{~N}$. after setting these conditions, samples were tested and the obtained results are shown in the table-12. Now by comparing all the results obtained by four ball test, it can be seen easily that the coefficient of friction drops from 0.06561 to 0.04973 while Wear Scar Diameter of $0.5 \% \mathrm{hBN}$ is highest from all the other results but $1 \%$ of $\mathrm{hBN}$ nanoparticles concentration shows the optimum value for Wear Scar Diameter (16).

\begin{tabular}{|c|c|c|c|}
\hline Sample \# & \% of Mahua oil in Castor Oil & hBN size $(\boldsymbol{\mu})$ & hBN \% \\
\hline \hline 1. & 35\% Mahua oil in 65\% castor Oil & 1.5 & 0 \\
\hline 2. & 35\% Mahua oil in 65\% castor Oil & 1.5 & 0.5 \\
\hline 3. & 35\% Mahua oil in 65\% castor Oil & 1.5 & 1 \\
\hline 4. & 35\% Mahua oil in 65\% castor Oil & 1.5 & 2 \\
\hline
\end{tabular}

Table-11 


\begin{tabular}{|c|c|c|c|c|c|c|c|}
\hline S \# & Sample Name & hBN \% & $\begin{array}{c}\text { Major } \\
\text { wear } \\
\text { scar Dia. } \\
\text { (mm) }\end{array}$ & $\begin{array}{c}\text { Min wear } \\
\text { scar Dia. } \\
\text { (mm) }\end{array}$ & $\begin{array}{c}\text { Avg. } \\
\text { wear } \\
\text { scar Dia. } \\
\text { (mm) }\end{array}$ & $\begin{array}{c}\text { Area } \\
\text { (mm }^{\mathbf{2}} \mathbf{m}\end{array}$ & COF \\
\hline \hline 1. & $\begin{array}{l}35 \% \text { Mahua oil in 65\% } \\
\text { castor Oil }\end{array}$ & $0 \%$ & 220 & 207 & 214 & 0.036 & 0.06561 \\
\hline 2. & $\begin{array}{l}35 \% \text { Mahua oil in 65\% } \\
\text { castor Oil }\end{array}$ & $0.5 \%$ & 248 & 321 & 240 & 0.045 & 0.06554 \\
\hline 3. & $\begin{array}{l}35 \% \text { Mahua oil in 65\% } \\
\text { castor Oil }\end{array}$ & $1 \%$ & 224 & 202 & 213 & 0.036 & 0.05365 \\
\hline 4. & $\begin{array}{l}35 \% \text { Mahua oil in 65\% } \\
\text { castor Oil }\end{array}$ & $2 \%$ & 230 & 198 & 214 & 0.036 & 0.04973 \\
\hline
\end{tabular}

Table-12

8. Experimental Investigation of Tribological Characteristics and Emissions with Nonedible Sunflower Oil as a Bio-lubricant: In this experiment, Tribological properties of sunflower oil under different loads condition were investigated and then the results obtained was compared with the commercial lubricating oil that SAE 40. In order to investigate the Tribological properties including the anti-wear and frictional property of the sunflower oil four ball tribometer is used and the four balls used in this experiment were made according to the requirement of ASTM D4172 that is chrome-alloy steel having $12.7 \mathrm{~mm}$ diameter, 25 grade $\mathrm{Eb}$, and 64-66 hardness. Moreover, the kinematic viscosity of the sunflower oil and mineral oil is also investigated that is shown in graph-4 and table-13. Wear scar diameter is measured by the optical and scanning electron microscope under high magnification of 50x. specimen (Sunflower oil \& mineral oil) is placed one after the other and load condition is increased from $30 \mathrm{~kg}$ to $45 \mathrm{~kg}$ along with $1200 \mathrm{rpm}$ for 60 minutes. It is observed that wear scar diameter for sunflower oil is 366 and $397 \mu \mathrm{m}$ which is smaller than the wear scar observed in case of mineral oil 383 and $413 \mu \mathrm{m}$ as shown in graph5. In this research, it is also discussed that this difference is occurred due to the presence of unsaturated fatty acids in sunflower oil that create a thin layer of soap on metallic surface. Along with wear scar, coefficient of friction of the sunflower oil and mineral oil is also calculated under the same load condition with $75^{\circ} \mathrm{C}$ and it is observed that sunflower oil show lower values in coefficient of friction than the mineral oil and it is increased with the increase of load as shown in graph-6. Now, by combining the results obtained, it is seen that the sunflower has an ability to be used as an alternative of mineral oil as a bio-lubricant (17).

\begin{tabular}{|c|c|c|}
\hline Kinematic Viscosity & ASTM & Results $\left(\mathbf{m m}^{\mathbf{2}} \mathbf{/ s}\right)$ \\
\hline \hline Viscosity @ $\mathbf{4 0}{ }^{\circ} \mathbf{C}$ & ASTM D445 & $>28.8$ \\
Viscosity @ $\mathbf{1 0 0 ^ { \circ } \mathrm { C }}$ & ASTM D445 & $>4.1$ \\
\hline
\end{tabular}

Table-13 


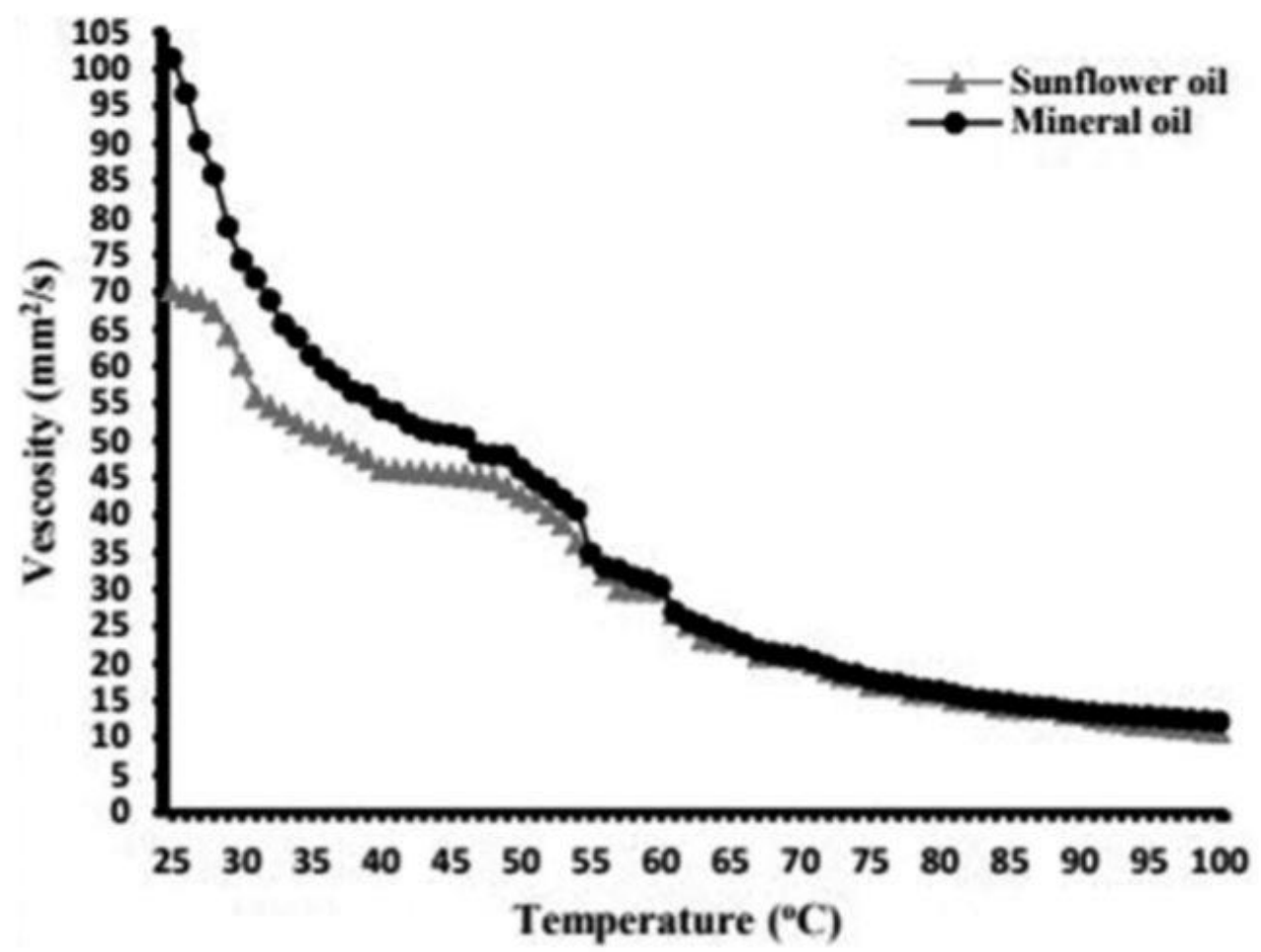

Graph-4

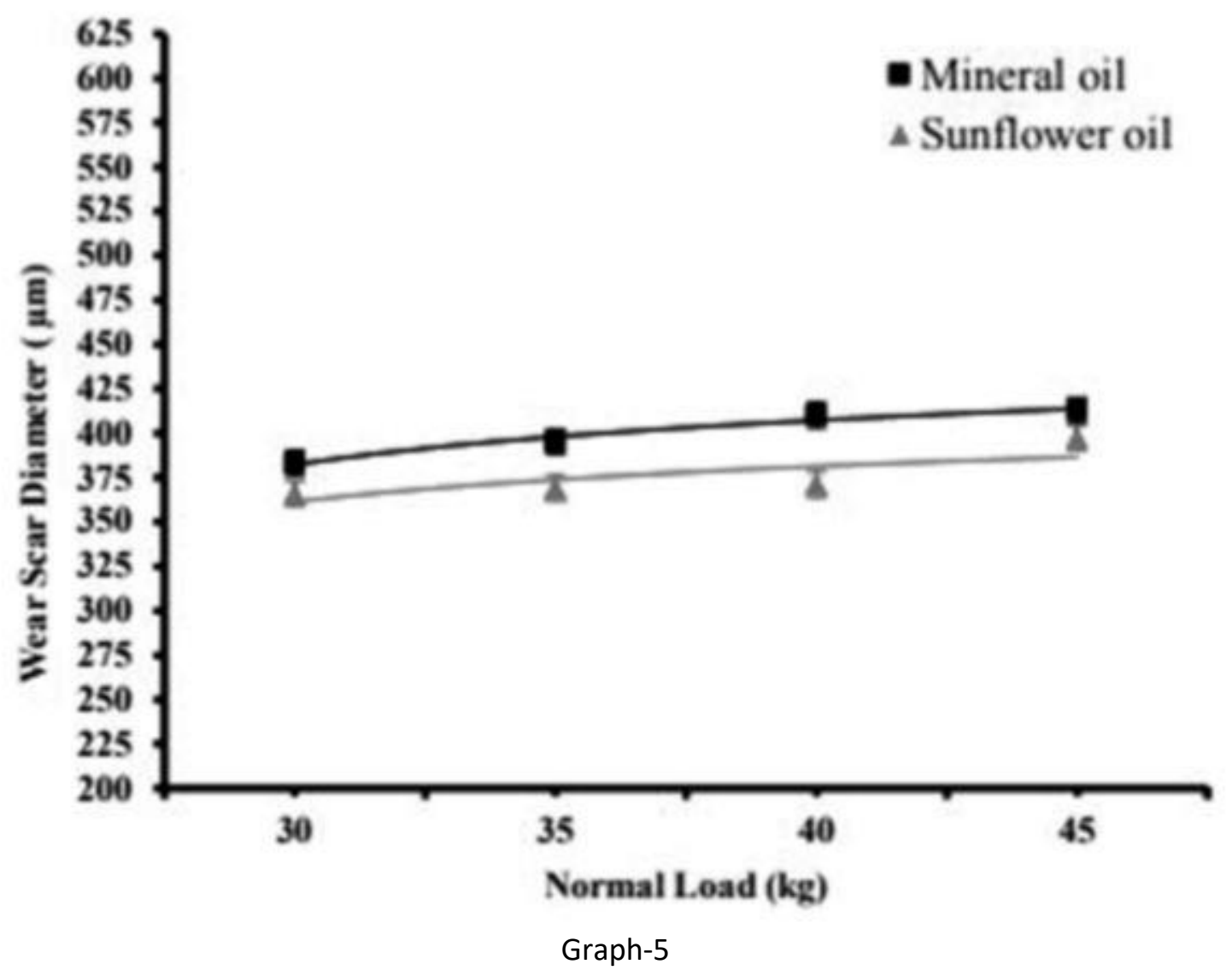




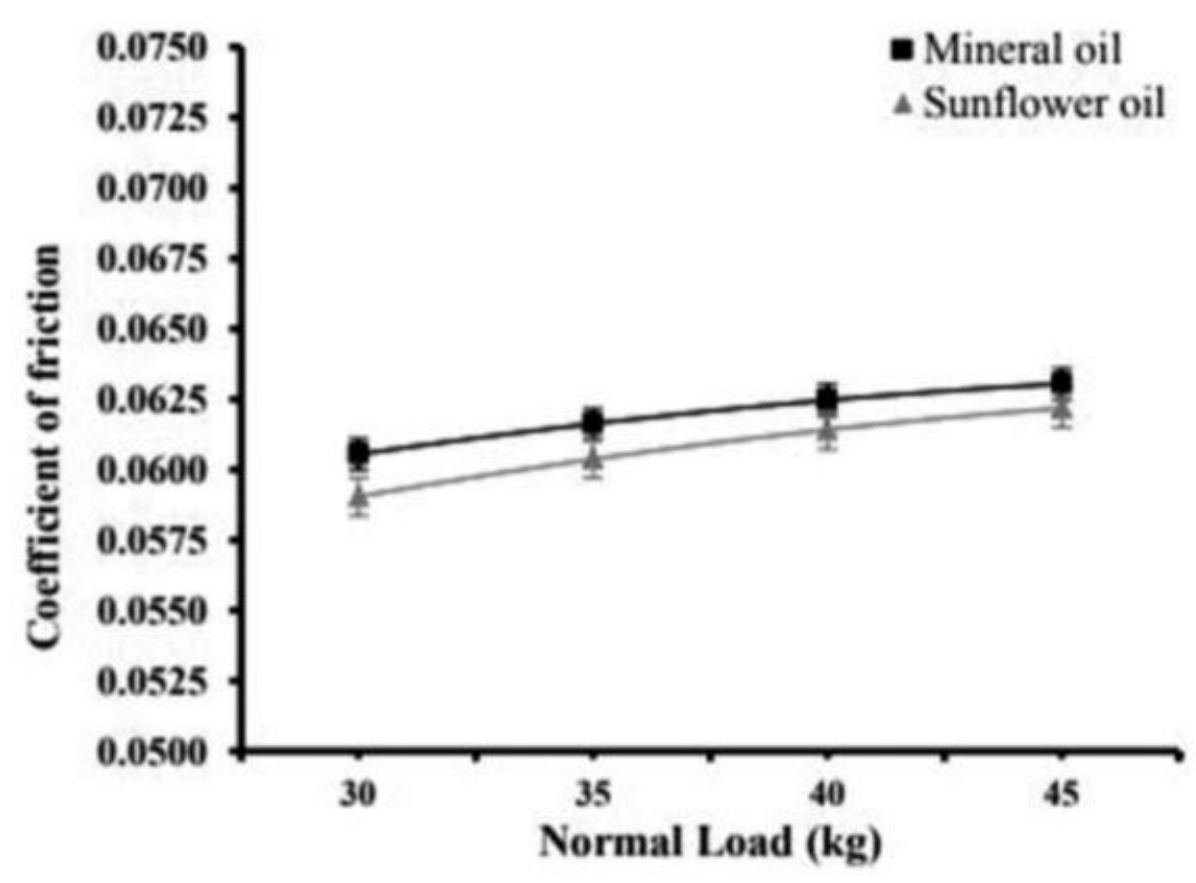

Graph-6

9. Investigation of Jatropha Oil as New Source of Lubricating Oil: In this research, Jatropha Oil is also investigated as a Bio-lubricant. In other research, Jatropha oil was investigated as a lubricating oil by four ball tribotester under various loads and temperature for measure antifriction and anti-wear ability, results of this experiment was compared with mineral hydraulic oil (10). In another research, Jatropha oil was also investigated as alternative source of engine and hydraulic oil under various temperature by four-ball tribotester and results confirm that this oil has higher lubricant ability to reduce friction and wear than mineral oil (18). Liaquat investigated the lubricant ability of Jatropha oil with different percentages of lubricants using a four-ball tribotester and employing loads of $15 \mathrm{~kg}$ and $40 \mathrm{~kg}$. the results show that Jatropha oil with 5\% lubricant showed effective anti-wear and anti-friction capabilities. Liaquat also compared 5\% Jatropha oil as a lubricant with a normal lubricant (SAE40 Grade) and results showed that 5\% Jatropha oil can be used as an alternative lubricant instead of a standard lubricant (19). Imam le at all, investigate the Jatropha oil as a new source of lubricant. In which they compared the viscosities of the Jatropha oil with the Hydraulic oil at $35^{\circ} \mathrm{C}, 55^{\circ} \mathrm{C}, 75^{\circ} \mathrm{C}, 95^{\circ} \mathrm{C}, 105^{\circ} \mathrm{C}$ and $120^{\circ} \mathrm{C}$. Results showed that at lower temperature hydraulic oil has higher viscosity on the other hand Jatropha oil has lower viscosity. But at higher temperature Jatropha oil has same viscosity as hydraulic oil as shows in graph-7. As a result, Jatropha oil will have higher viscosity index as compared to the hydraulic oil. Furthermore, anti-wear and anti-friction properties of the Jatropha oil is also compared with the Hydraulic oil. Results showed that some parallel scratches observed on the surface of the balls using a Jatropha oil at $75^{\circ} \mathrm{C}$ and $105^{\circ} \mathrm{C}$ shows in figure-10. On the other hand, deep grooves with some of the pits are observed on the surface of the balls using hydraulic oil at $75^{\circ} \mathrm{C}$ shows in figure11. Overall results showed that the Jatropha oil has less wear and friction as compared to the hydraulic oil as shows in graph-8 (10). 

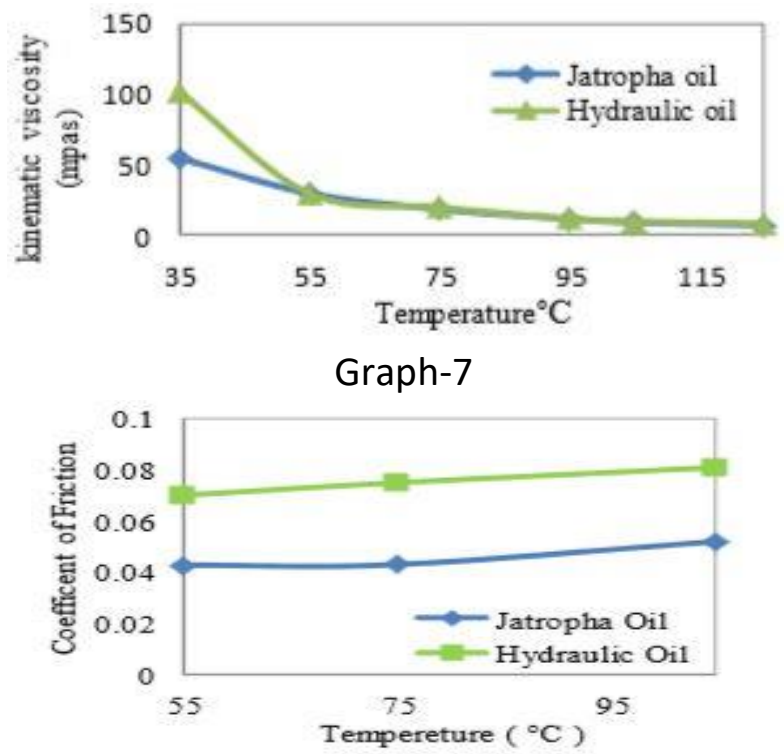

Graph-8
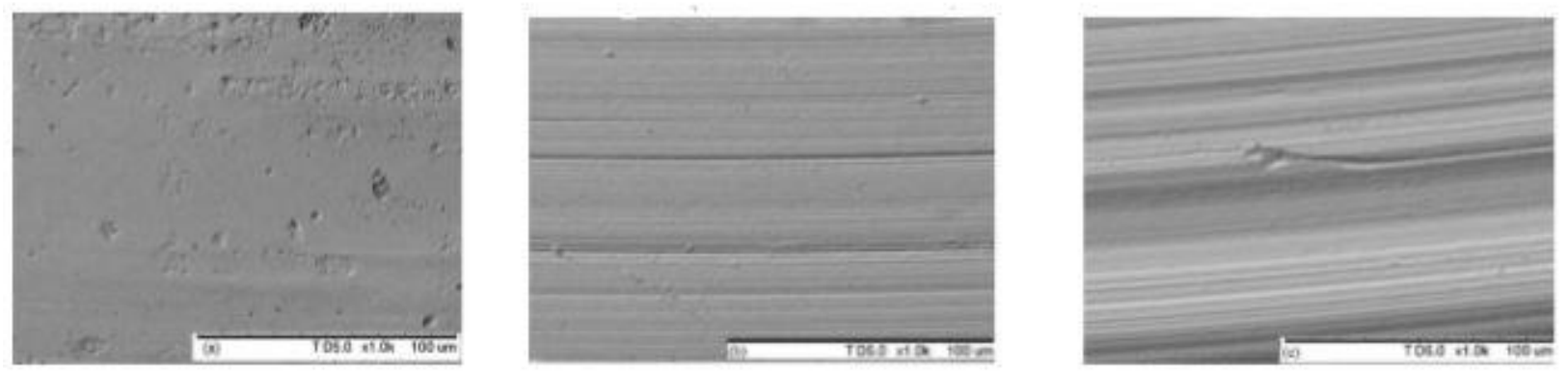

Figure-10
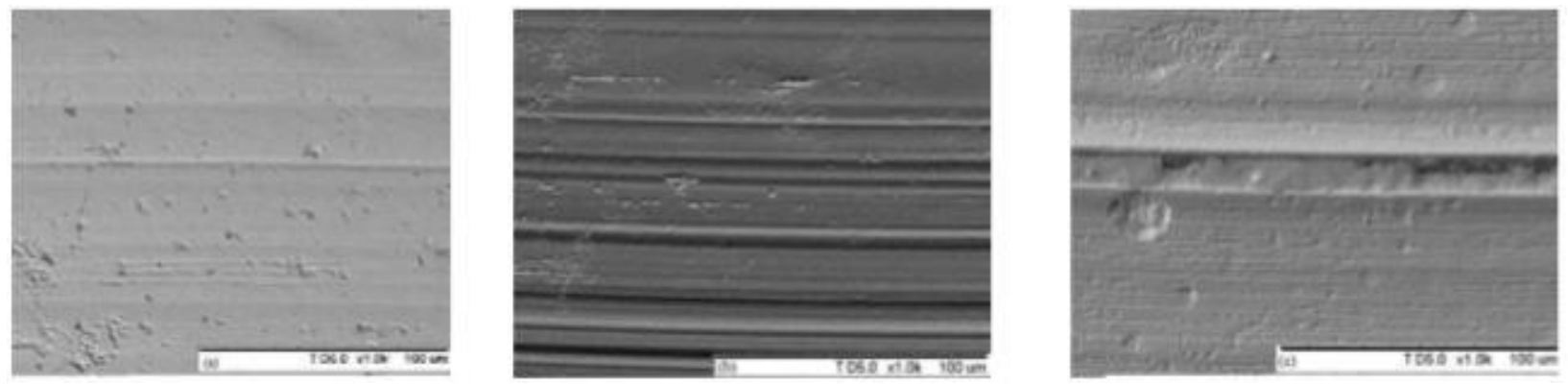

Figure-11

10. Analysis of Tribological behavior vegetable oil-based lubricant with nanoparticles of oxides in boundary lubrication conditions: This research analysis the results upon addition of oxides nanoparticles $(\mathrm{ZnO}$ and $\mathrm{CuO})$ in different base oil: soybean, sunflower, mineral and synthetic oils, to investigate the tribological behavior of lubricants. As it is demanded that there should be a replace for non-biodegradable and toxic mineral based lubricant. As the good mixture of based oil and additive is important to improve the lubricating characteristics, low concentration additive is sufficient below $2 \mathrm{wt} \%$ and $0.5 \mathrm{wt} \%$ is proof to be optimum. Conventional additives like chlorine and phosphorus are not environmental friendly, therefore, new additives have been 
investigated and oxides of $\mathrm{Zn}$ and $\mathrm{Cu}$ have been proved to be best ones. They have both excellent tribological and environmental friendly properties. Its excellent anti-wear and friction reducing properties make it the suitable nanoparticle as it forms film of metallic copper on the steel film. High frequency reciprocating test rig (HFRR) equipment were used to study anti-wear behavior and SEM/EDS analysis of worn surfaces and electrical contact resistance(ECR) technique was used measure mass formulation of electrically insulating film and coefficient of friction was measured by using pie20 electric transducer. The reaction was catalyzed with $4 \%$ sulfuric acid glass reactor at 50 degrees Celsius for reaction time of 5 hours. Oils were analyzed in the form of viscosity, density and iodine value. The density and viscosity were find by pycnometer Brookfield RS 2000 and rheometer respectively. Table-14 shows the characteristics being studied. The coefficient of friction for all lubricants are shown in figure 12a-d. Table-2 also compares the mean $\mathrm{COF}$ and standard deviation. The performance with and without additive has been analyzed, the mineral and synthetic oil have high COF without additives, while addition of additives decreases the COF, however, this behavior was not seen in vegetable based oils. Worn disc surface morphologies and chemical distribution were studied by SEM equipped with EDS figure 13(a-b) evaluated the anti-wear ability of vegetable oil and shows that there is no severe scuffing and have better results than mineral and synthetic oils. The drawback is that the bio-lubricants have poor oxidative and thermal stability due to presence of unsaturation which needs to be solved (20).

\begin{tabular}{llll}
\hline & $\begin{array}{l}\text { Density } \\
\left(\mathrm{g} / \mathrm{cm}^{3}\right)\end{array}$ & $\begin{array}{l}\text { lodine number } \\
\left(\mathrm{g} \mathrm{I}_{2} / 100 \mathrm{~g}\right)\end{array}$ & $\begin{array}{l}\text { Viscosity } \\
\text { (cSt) at 40 1C }\end{array}$ \\
\hline Soybean oil & 0.97988 & 4.8340 & 144.72 \\
Sunflower oil & 0.98052 & 4.8478 & 149.04 \\
Mineral oil & 0.8474 & - & 45.70 \\
Synthetic oil & 0.8303 & - & 79.92 \\
\hline
\end{tabular}

Table-14 Physical and chemical properties of soybean oil and sunflower epoxidized
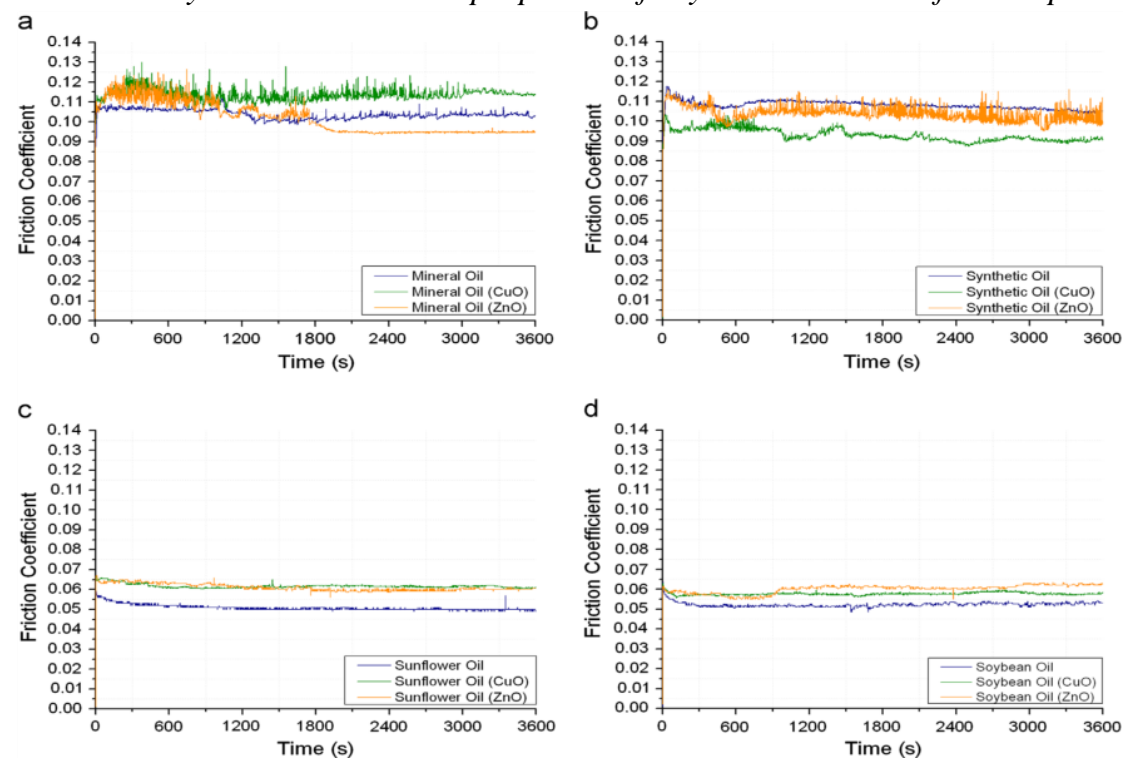

Figure: $12(\mathrm{a}-\mathrm{d})$ 
a

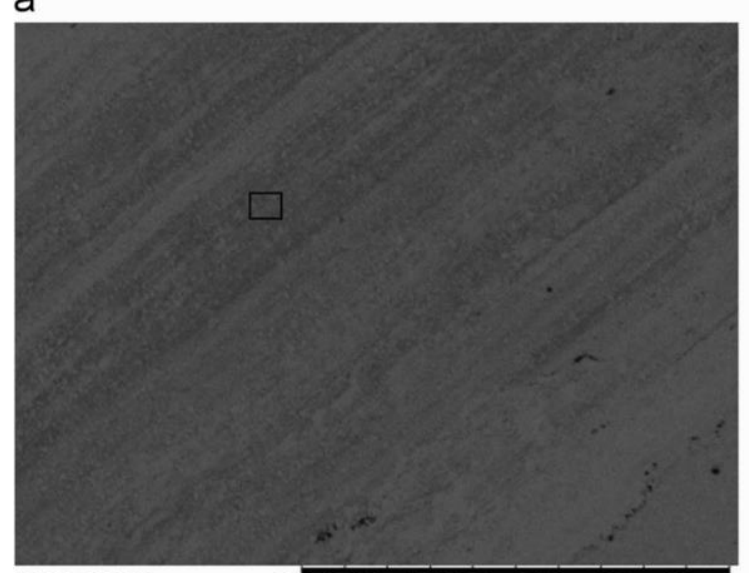

DEMat-UFRN

$2012 / 06 / 18 \quad 17: 15 \mathrm{FL} \quad \mathrm{D5} .6 \times 1.0 \mathrm{k} \quad 100 \mathrm{um}$

C

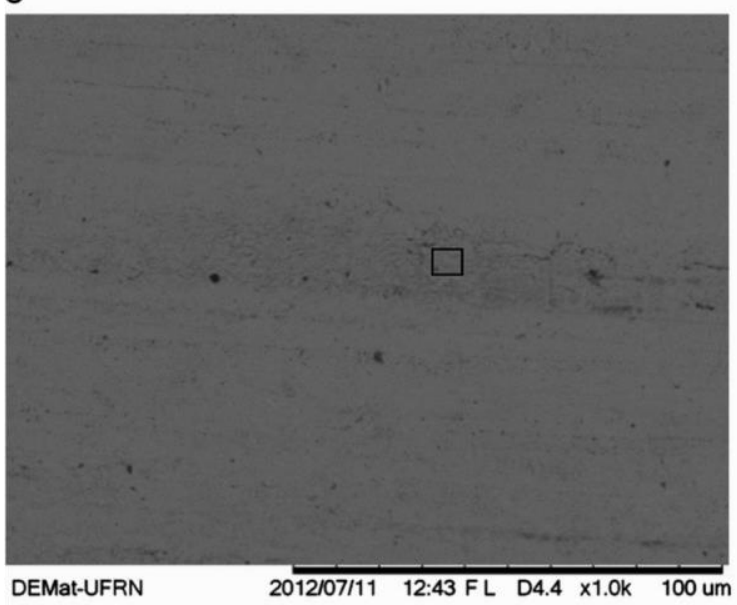

e

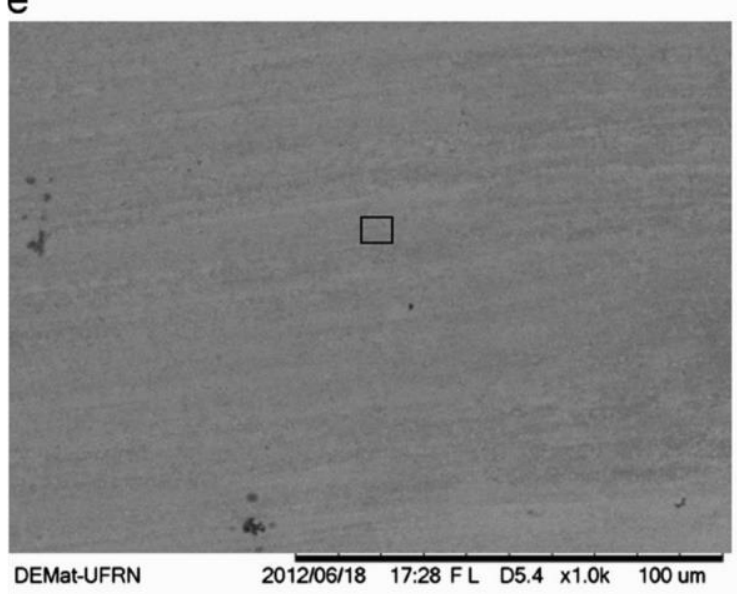

b

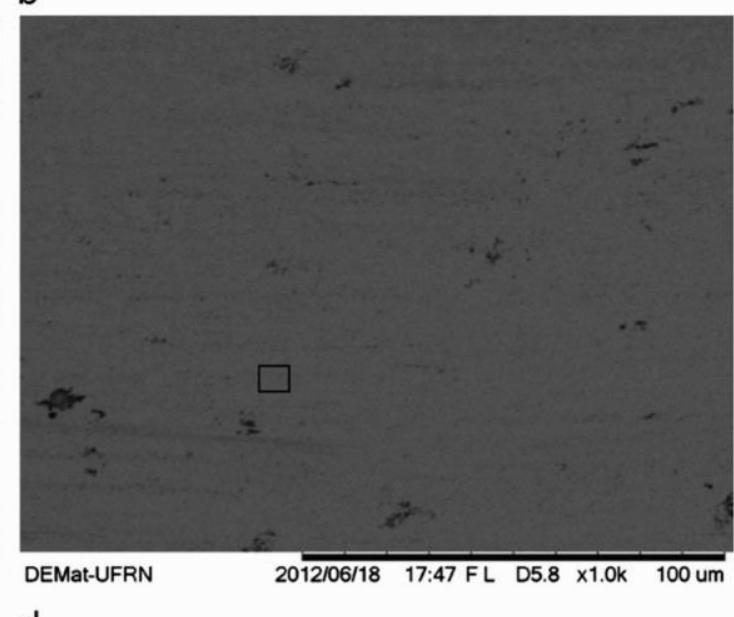

d

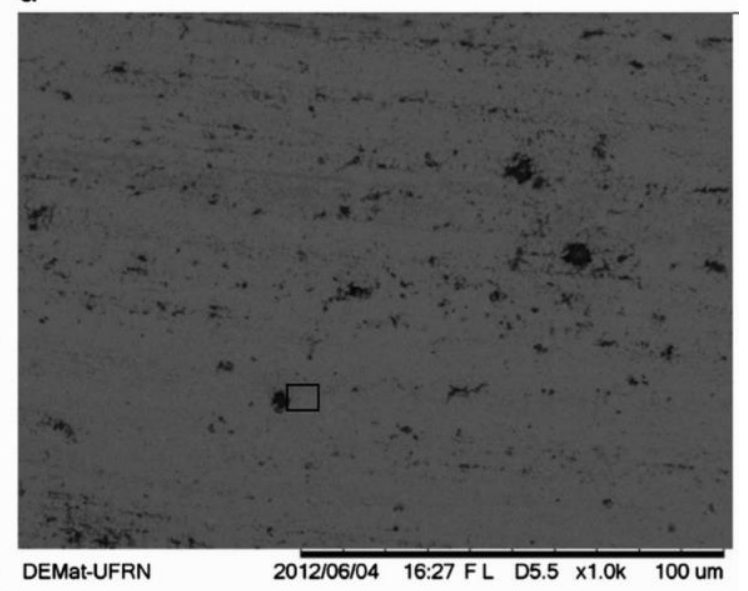

f

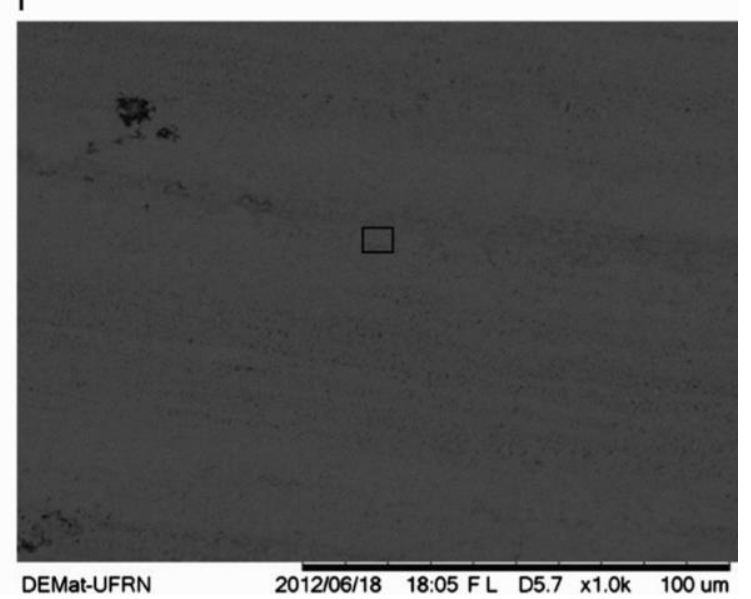

Figure: 13 (a-f)

11. Analysis of Lubrication Properties of Zinc-dialkyl-dithio-phosphate (ZDDP) Additive on Karanja Oil (Pongamia Pinnatta) as a Green Lubricant: In this research, wear property of karanja oil is analyzed as compared to the mineral based lubricant SAE 20W-40. In which, they used international standard experiment equipment include: four ball with chromium alloy steel ball for wear and friction property, viscometers to find viscosity at $40^{\circ} \mathrm{C}$ and $100^{\circ} \mathrm{C}$. other chemical 
and physical properties is also analyzed as per American Oil Chemist's Society methods. In order to enhance the anti-wear properties of Karanja Oil, an additive is used in different proportion. ZDDP is used as an anti-wear additive and added in Karanja Oil with 1\%, 1.5\%, 2\%, 2.5\% and $3 \%$. It is observed that the addition of ZDDP lower the Coefficient of friction (COF) and wear scar diameter (WSD) of the balls. Like 1\% addition of ZDDP lower the COF and WSD similarly $1.5 \%$ and $2 \%$ further lower the COF and WSD but the further increase of ZDDP in Karanja Oil increases the COF and WSD as shown in table-15. On the other side, thermal properties of vegetable oil are affected by the adding the ZDDP additive. Like it increases its viscosity index as shown in table1 and flash point also increases as shown in table-16. Over all, karanja oil with2\% ZDDP showed a viscosity index of (155) which is higher than the SAE grade $20 \mathrm{~W} 40$ oil (123). Flash point and fire point od additive added Karanja oil have higher values ( $254 \& 266)$ as compared to SAE 20W40 but the pour point of the Karanja Oil is above the mineral oil's pour point that is the main drawback of vegetable oil (Karanja Oil) (21).

\begin{tabular}{|c|c|c|c|}
\hline Oil name & $\begin{array}{c}\text { Coefficient of } \\
\text { friction (COF) }\end{array}$ & $\begin{array}{c}\text { Wear scar } \\
\text { diameter } \\
\text { (WSD) in } \\
\text { micrometer }\end{array}$ & $\begin{array}{c}\text { Viscosity } \\
\text { index }\end{array}$ \\
\hline Karanja oil & 0.0551 & 462.99 & 146 \\
\hline Servo oil & 0.0478 & 500.89 & 123 \\
\hline $\begin{array}{c}\text { Karanja oil }+1.0 \% \\
\text { ZDDP }\end{array}$ & 0.0434 & 457.23 & 162 \\
\hline $\begin{array}{c}\text { Karanja oil }+1.5 \% \\
\text { ZDDP }\end{array}$ & 0.0430 & 428.56 & 152 \\
\hline $\begin{array}{c}\text { Karanja oil }+2.0 \% \\
\text { ZDDP }\end{array}$ & 0.0424 & 405.35 & 155 \\
\hline $\begin{array}{c}\text { Karanja oil }+2.5 \% \\
\text { ZDDP }\end{array}$ & 0.0487 & 433.43 & 157 \\
\hline $\begin{array}{c}\text { Karanja oil }+3.0 \% \\
\text { ZDDP }\end{array}$ & 0.0504 & 492.87 & 153 \\
\hline
\end{tabular}

Table-15

\begin{tabular}{|c|c|c|c|c|}
\hline Oil name & $\begin{array}{c}\text { flash point } \\
\text { in }{ }^{\circ} \mathrm{C}\end{array}$ & $\begin{array}{c}\text { fire } \\
\text { point in } \\
{ }^{\circ} \mathrm{C}\end{array}$ & $\begin{array}{c}\text { pour } \\
\text { point in } \\
{ }^{\circ} \mathrm{C}\end{array}$ & $\begin{array}{c}\text { Cloud point } \\
\text { in }{ }^{\circ} \mathrm{C}\end{array}$ \\
\hline Mineral oil & 230 & 260 & -6 & -3 \\
\hline Karanja oil & 251 & 260 & 1 & 4 \\
\hline $\begin{array}{l}\text { Karanja oil + } \\
2.0 \% \text { ZDDP }\end{array}$ & 254 & 266 & 1 & 3 \\
\hline
\end{tabular}

Table-16

\section{Modification:}

In different researches, it is observed that the vegetable oil can be used as an alternative to the mineral oil lubricants but one of the drawback that is observed other than flash point, fire point, viscosity index, wear and friction properties of the vegetable oil was a pour point in comparison with the mineral base oil. The pour point of the vegetable oil in case of karanja oil is greater than the mineral oil as shown in table-16. Mineral oils usually have a pour point minimum $-6^{\circ} \mathrm{C}$ or in 
some cases the pour point is approximately about $-18^{\circ} \mathrm{C}$ while on the other hand, vegetable oil (Karanja oil) has a pour point $1^{\circ} \mathrm{C}$ that may be a problem in usage at low temperature areas. In modification of vegetable oil, we investigate the different additives for the improvement of pour point of karanja oil.

Different additives like copolymers of ethylene acrylic acid, polymethacrylate and Ethylene Vinyl Acetate Copolymer are used in different proportion with the karanja oil as shown in table-17. In order to find out its compatibility and efficiency with karanja oil.

\begin{tabular}{|c|l|l|l|c|}
\hline Sample \# & Vegetable oil & Additive (PPD) & Proportion & Results $\left(^{\circ} \mathbf{C}\right)$ \\
\hline \hline $\mathbf{1 .}$ & Karanja oil & Ethylene acrylic acid & $99: 1$ & -3 \\
\hline $\mathbf{2 .}$ & Karanja oil & Ethylene acrylic acid & $99.5: 0.5$ & -2 \\
\hline $\mathbf{3 .}$ & Karanja oil & Ethylene acrylic acid & $99.75: 0.25$ & -2 \\
\hline $\mathbf{4 .}$ & Karanja oil & Ethylene acrylic acid & $99.9: 0.1$ & 0 \\
\hline $\mathbf{5 .}$ & Karanja oil & Ethylene Vinyl Acetate & $99: 1$ & -5 \\
\hline $\mathbf{6 .}$ & Karanja oil & Ethylene Vinyl Acetate & $99.5: 0.5$ & -5 \\
\hline $\mathbf{7 .}$ & Karanja oil & Ethylene Vinyl Acetate & $99.75: 0.25$ & -3 \\
\hline $\mathbf{8 .}$ & Karanja oil & Ethylene Vinyl Acetate & $99.9: 0.1$ & -1 \\
\hline $\mathbf{9 .}$ & Karanja oil & Polymethacrylate & $99: 1$ & -11 \\
\hline $\mathbf{1 0 .}$ & Karanja oil & Polymethacrylate & $99.5: 0.5$ & -9 \\
\hline $\mathbf{1 1 .}$ & Karanja oil & Polymethacrylate & $99.75: 0.25$ & -6 \\
\hline $\mathbf{1 2 .}$ & Karanja oil & Polymethacrylate & $99.9: 0.1$ & -2 \\
\hline
\end{tabular}

Table-17

The above results plotted on graph-9 in order to observe the trend in lowering the pour point.

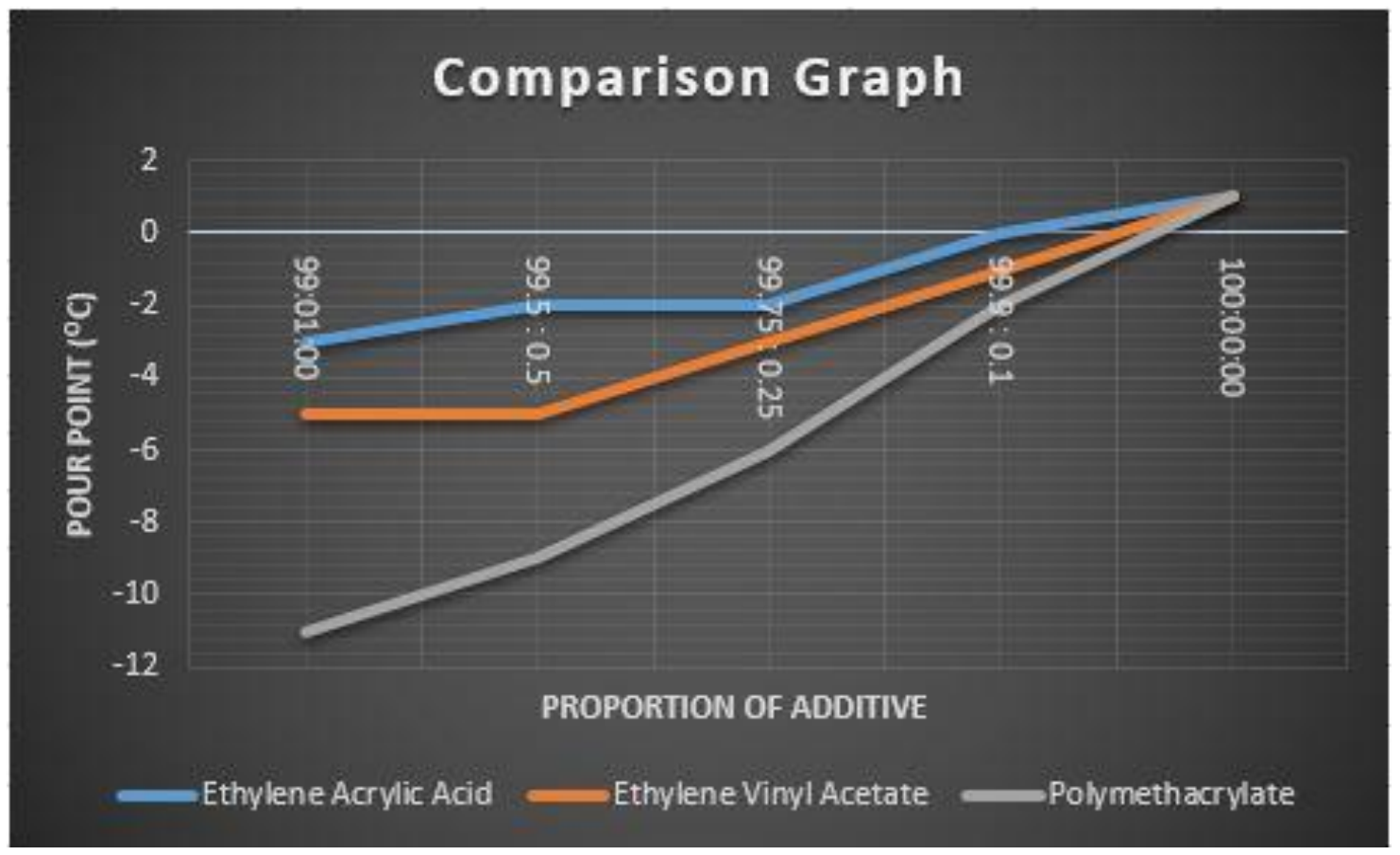

Graph-9 
By comprising the results of the addition of three different additives in karanja oil in a single graph. It is observed that the addition of pour point depressant in the karanja oil lower the pour point of karanja oil. Addition of $0.1 \%$ Ethylene Acrylic acid, Ethylene Vinyl Acetate and Polymethacrylate in karanja oil lower the pour point from $1{ }^{\circ} \mathrm{C}$ to the $0^{\circ} \mathrm{C},-1^{\circ} \mathrm{C}$ and $-2^{\circ} \mathrm{C}$ respectively. Similarly, on higher concentration of additive in karanja oil further lower the pour point like $1 \%$ addition of Ethylene Acrylic acid, Ethylene Vinyl Acetate and Polymethacrylate lower the pour point from $1^{\circ} \mathrm{C}$ to $-3^{\circ} \mathrm{C},-5^{\circ} \mathrm{C}$ and $-11^{\circ} \mathrm{C}$ respectively. Best results are shown by polymethacrylate in this addition of additives while the least results are shown by Ethylene Acrylic Acid. Along with the lowering in pour point of karanja oil with the addition of additives, it was observed that when the concentration of Ethylene Acrylic acid and Ethylene Vinyl Acetate increases from $0.5 \%$. It gets separate from karanja oil after 45 minutes. But in case of Polymethacrylate, it does not separate even at higher concentration of about $2 \%$ by setting it for more than 48 hours. So overall results show that the most compatible additive for lowering the pour point of karanja oil is Polymethacrylate.

\section{Conclusion:}

As growing demand of mineral based lubricants arise the research on the vegetable as a biolubricant due to its bio-degradability that make the lubricant environmental friendly. Different researches shows that the Tribological properties of vegetable oil blended with the anti-wear additive is more acceptable than the mineral oil. On the other side, vegetable oil has also an ability to oxidize less than the mineral oil that has its high viscosity index while high flash point than the mineral oil makes the vegetable oil low evaporation rates. In case of karanja oil, it has a drawback of pour point that is high than the mineral oil. But in the modification of karanja oil, the pour point is improved by the addition of Ethylene Acrylic acid, Ethylene Vinyl Acetate and Polymethacrylate. Best results are shown by Polymethacrylate, that it lowers the pour point from $1^{\circ} \mathrm{C}$ to $-11^{\circ} \mathrm{C}$ on the addition of $1 \%$ in karanja oil.

\section{Acknowledgement:}

This paper is a part of M.Sc. research work. We (Authors) would like to thank CEO Mr. Hamid Shah, Well Lubricant (Lubricants Manufacturing Company), Pakistan, who allowed me to carry out test in Laboratory of the Company. Also great thanks to Engineer Aqeel, Production Team Leader, Well Lubricant, Pakistan. Who helped me to figure out these results suitable for industry. 


\section{References:}

1. Biodiesel : the comprehensive handbook (Book, 2004) [WorldCat.org] [Internet]. [cited 2020 Aug 12]. Available from: https://www.worldcat.org/title/biodiesel-thecomprehensive-handbook/oclc/57564284

2. World Lubricant Demand to Reach 40.5 Million Metric Tons in 2012 [Internet]. [cited 2020 Aug 12]. Available from: https://www.machinerylubrication.com/Read/1983/worldlubricant-dem-to-reach-405-million-metric-tons-in-2012

3. Prerna Singh Chauhan and Dr. V K Chhibber "Non-Edible Oil as a Source of BioLubricant for Industrial Applications: A Review" International Journal of Engineering Science and Innovative Technology (IJESIT) Volume 2, Issue 1, January 2013 - Google Search [Internet]. [cited 2020 Aug 12]. Available from: https://www.google.com/search?q=Prerna+Singh+Chauhan+and+Dr. $+\mathrm{V}+\mathrm{K}+\mathrm{Chhibber}+$ "N on-Edible+Oil+as+a+Source+of+Bio-

Lubricant+for+Industrial+Applications $\% 3 \mathrm{~A}+\mathrm{A}+$ Review"+International+Journal+of+Engi neering+Science+and+Innovative+Technology+(IJESIT)+Volume $+2 \% 2 \mathrm{C}+$ Issue $+1 \% 2 \mathrm{C}+$ January $+2013 \&$ oq $=$ Prerna + Singh + Chauhan + and + Dr. + V + K + Chhibber + "Non-

Edible+Oil+as+a+Source+of+Bio-

Lubricant+for+Industrial+Applications $\% 3 \mathrm{~A}+\mathrm{A}+$ Review"+International+Journal+of+Engi neering+Science+and+Innovative+Technology+(IJESIT)++Volume+2\%2C+Issue+1\%2C + January+2013\&aqs $=$ chrome..69i57.935j0j7\&sourceid $=$ chrome\&ie $=U T F-8$

4. Trans esterification studies on castor oil as a first step towards its use in bio diesel production [Internet]. [cited 2020 Aug 12]. Available from: https://agris.fao.org/agrissearch/search.do?recordID=PK2010001241

5. Robles-Medina A, González-Moreno PA, Esteban-Cerdán L, Molina-Grima E. Biocatalysis: Towards ever greener biodiesel production. Biotechnol Adv [Internet]. 2009 Jul 4 [cited 2020 Aug 12];27(4):398-408. Available from: https://linkinghub.elsevier.com/retrieve/pii/S0734975009000445

6. Nagendramma P, Kaul S. Development of ecofriendly/biodegradable lubricants: An overview. Vol. 16, Renewable and Sustainable Energy Reviews. Pergamon; 2012. p. 764 74.

7. Cheenkachorn K. A study of wear properties of different soybean oils. In: Energy Procedia. Elsevier Ltd; 2013. p. 633-9.

8. Sanni SE, Odigure JO, Efeovbokhan V, Emetere ME. Comparative Study of Lube Oils Syhthesized from Chemically Modified Castor and Soybean Oils Using Additive. Sci Eng Appl. 2017 Feb 10;2(2):134.

9. Viscosity [Internet]. [cited 2020 Aug 12]. Available from: http://www.synlube.com/viscosit.htm

10. (PDF) Investigate Jatropha Oil as New Source Of Lubricant Oil [Internet]. [cited 2020 Aug 12]. Available from: https://www.researchgate.net/publication/264084512_Investigate_Jatropha_Oil_as_New_ 
Source_Of_Lubricant_Oil

11. Zulkifli NWM, Azman SSN, Kalam MA, Masjuki HH, Yunus R, Gulzar M. Lubricity of bio-based lubricant derived from different chemically modified fatty acid methyl ester. Tribol Int. 2016 Jan 1;93:555-62.

12. Mobarak HM, Niza Mohamad E, Masjuki HH, Kalam MA, Al Mahmud KAH, Habibullah M, et al. The prospects of biolubricants as alternatives in automotive applications. Vol. 33, Renewable and Sustainable Energy Reviews. 2014. p. 34-43.

13. ASTM D2783 - 19 Standard Test Method for Measurement of Extreme-Pressure Properties of Lubricating Fluids (Four-Ball Method) [Internet]. [cited 2020 Aug 12]. Available from: https://www.astm.org/Standards/D2783.htm

14. ASTM D445 : Standard Test Method for Kinematic Viscosity of Transparent and Opaque Liquids (and Calculation of Dynamic Viscosity) [Internet]. [cited 2020 Aug 12]. Available from: https://global.ihs.com/doc_detail.cfm?document_name=ASTM D445\&item_s_key=00018647

15. Peethambaran KM, Mahipal M. Anti-Wear Properties of Benzoic Acid in Karanja Oil [Internet]. Vol. 4, Journal of Engineering Research and Applications www.ijera.com. 2014 [cited 2020 Aug 12]. Available from: www.ijera.com

16. Umaji MNA. Experimental Analysis of Tribological Properties of HBN Nanoparticles Additive in Castor \& Mahua Oil Blend. Int J Res Appl Sci Eng Technol. 2018 Jan 31;6(1):1451-5.

17. Jabal MH, Abdulmunem AR, Abd HS. Experimental investigation of tribological characteristics and emissions with nonedible sunflower oil as a biolubricant. J Air Waste Manag Assoc. 2019 Jan 2;69(1):109-18.

18. Samion S. Investigation of the Physical Properties for Jatropha Oil in Different Temperature as Lubricant Oil [Internet]. [cited 2020 Aug 15]. Available from: https://www.academia.edu/36977319/Investigation_of_the_Physical_Properties_for_Jatro pha_Oil_in_Different_Temperature_as_Lubricant_Oil

19. Ab Gapor Md Top. Production and utilization of palm fatty acid distillate (PFAD). Lipid Technol [Internet]. 2010 Jan 1 [cited 2020 Aug 15];22(1):11-3. Available from: http://doi.wiley.com/10.1002/lite.200900070

20. Alves SM, Barros BS, Trajano MF, Ribeiro KSB, Moura E. Tribological behavior of vegetable oil-based lubricants with nanoparticles of oxides in boundary lubrication conditions. In: Tribology International. Elsevier Ltd; 2013. p. 28-36.

21. D M, P. K, Rafeekh P M, N.H. J. Analysis of lubrication properties of zinc-dialkyl-dithiophosphate (ZDDP) additive on Karanja oil (Pongamia pinnatta) as a green lubricant. Int J Eng Res. 2014 Aug 1;3(8):494-6. 